\title{
格子ボルツマン法による円管内流れの数值シミュレーション
}

\section{Numerical Simulation of Fluid Flow in Circular Pipe by the Lattice Boltzmann Method}

\author{
中西 喬也 (信州大院)＼cjkstart村山 寿郎 (信州大院) \\ 正 吉野 正人（信州大工）
}

Takaya NAKANISHI, Graduate School, Shinshu University, 4-17-1 Wakasato, Nagano 380-8553, Japan Toshiro MURAYAMA, Graduate School, Shinshu University Masato YOSHINO, Shinshu University

Key Words: Lattice Boltzmann Method (LBM), Pipe Flow, Two-Phase Flow

\section{1.は じめ に}

円管内を流れる流体は工学の分野だけでなく, 医学におけ る血管内の流れなど様々な分野で見ることができる. 円管内で の流体が壁面に与える影響や流体の輸送効率の観点から，こ のような流れ場を解析することは非常に重要である.

近年, 非圧縮粘性流体の新しい計算法として, 格子ボルツ マン法 (Lattice Boltzmann Method, 以下 LBM) ${ }^{(1)}$ が提案さ れているが, LBM では計算手法がデカルト座標を基礎とする ために，円管のような曲率のある流路では境界が格子点上に ないため, 何らかの近似が必要になるという問題が挙げられ る. 既存の研究では, 埋め込み境界法 (Immersed Boundary Method）を用いた円柱周りの流机解析 ${ }^{(2)(3)} に$ におて, 格子 点上にない境界条件が様々提案されているが, まだ完全に確 立されているとは言い難い.

そこで本研究では，LBM における円管形状を表す新たな 境界条件を提案した. また，二相系 LBM に本手法を組み込 み, 円管内のポアズイユ流中における粒子の解析を行った。

\section{2. 計算手法および境界条件}

本研究で用いる LBM および等密度の二相系 LBM は文献 (1) および (4)を参照されたい. 本節では新たに提案した境界 条件について述べる.また本計算では，LBM の発展形であ る格子運動論スキーム (Lattice Kinetic Scheme) ${ }^{(1)}$ を用いる. 格子運動論スキームでは，通常の数值計算法と同様に巨視的 変数を用いた境界条件を適用できる。本研究では，アルゴリ ズムを複雑にせず，以下の近似方法を用いて，曲率をもつ境 界に対し流速および圧力の補間を行った. 本手法は, デカル 卜座標で表される立方格子で分割された計算領域内に円管を 配置し，その内部領域を計算対象とする. まずFig. 1 に示す ように，円管を表す真の境界 (太線) 近傍において，周囲の 格子点に少なくとも一つ境界の外側の点を含む格子点を境界 点 (•)とし, その内側の格子点 (o) と区別する.このように 識別された境界点において, 円管の真の壁面ですべりなし壁 となるように流速 $\boldsymbol{u}$ および圧力 $p$ を近似により与える.すな わち, Fig. 2 に示すように境界点 B での流速 $\boldsymbol{u}_{\mathrm{B}}$ は以下の式 から二次曲線によって補間し求めた。

$$
\boldsymbol{u}_{\mathrm{B}}=\frac{\left[R^{2}-\left(R-\delta r_{1}\right)^{2}\right]}{R^{2}-\left(R-\delta r_{1}-\delta r_{2}\right)^{2}} \boldsymbol{u}_{\mathrm{a}}
$$

ここで, $\boldsymbol{u}_{\mathrm{a}}$ は点 aにおける流速であり, 両隣の 2 点 $\mathrm{a} 1$, a2 における既知の流速を用いて内挿によって求める. なお, 点 $\mathrm{a}$ は点 $\mathrm{B}$ を通る円管の法線と $\mathrm{a} 1 ， \mathrm{a} 2$ と結ぶ線分の交点であ り, $\delta r_{1}$ は点 $\mathrm{W}$ から点 $\mathrm{B}$ までの長さ, $\delta r_{2}$ は点 $\mathrm{B}$ から点 $\mathrm{a}$ ま での長さをそれぞれ表す。

次に, 圧力は壁上の点 $\mathrm{W}$ において法線方向の圧力勾配 $\partial p / \partial n=0$ になるように, 境界点 $\mathrm{B}$ における圧力 $p_{\mathrm{B}}$ を求め る.はじめに, 点 $\mathrm{W}$ の压力 $p_{\mathrm{W}}$ を二次精度の差分近似を用 いて以下の式から求める.

$$
p_{\mathrm{W}}=\frac{4 p_{\mathrm{a}}-p_{\mathrm{c}}}{3},
$$

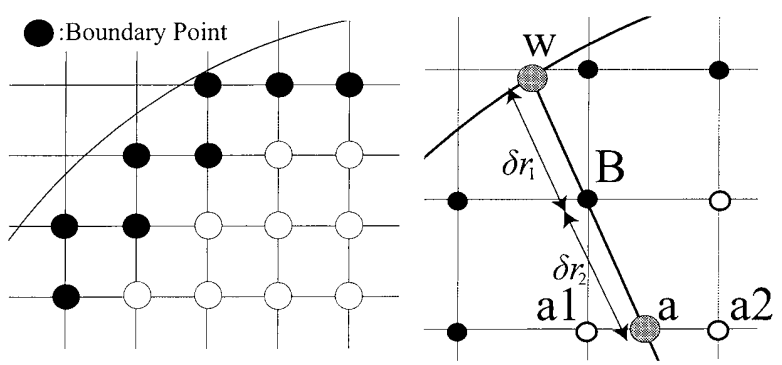

Fig. 1 Boundary Points. Fig. 2 Interpolation in veloc-

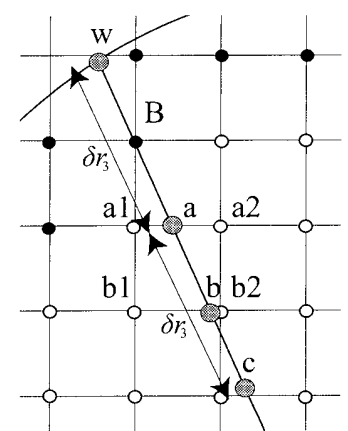

(a) Step 1

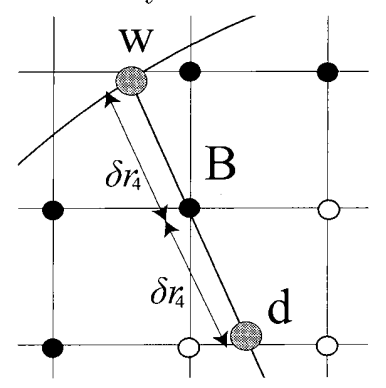

(b) Step 2
Fig. 3 Interpolation in pressure.

ここで, $p_{\mathrm{a}}$ は点 a における圧力であり, 流速 $\boldsymbol{u}_{\mathrm{a}}$ と同様の方 法で求める. 同様に, $p_{\mathrm{b}}$ は同法線と 2 点 $\mathrm{b} 1, \mathrm{~b} 2$ を結ぶ線分 との交点 bにおける圧力であり， $\delta r_{3}$ は点 $\mathrm{W}$ から点 $\mathrm{a}$ までの 長さである. さらに, 同法線上に点 $\mathrm{a}$ より長さ $\delta r_{3}$ の位置に ある点を $\mathrm{c}$ とする. また, 点 $\mathrm{c}$ における圧力 $p_{\mathrm{c}}$ は, Fig. 3(a) に示す 2 点 $\mathrm{a}, \mathrm{b}$ における既知の圧力值より一次精度の外挿 によって求める. 次に, Fig. 3(b) に示すように, (2) 式から 求めた $p_{\mathrm{w}}$ と点 $\mathrm{d}$ における圧力 $p_{\mathrm{d}}$ を用いて上記と同様に二次 精度の差分近似を用いて, 境界上の圧力勾配が 0 になるよう に以下の式から境界点 $\mathrm{B}$ での圧力 $p_{\mathrm{B}}$ を求める.

$$
p_{\mathrm{B}}=\frac{3 p_{\mathrm{W}}+p_{\mathrm{d}}}{4},
$$

ここで, 点 $\mathrm{d}$ は点 $\mathrm{W}$ から点 $\mathrm{B}$ までの長さ $\delta r_{4}$ と点 $\mathrm{B}$ からの 長さが等しくなる法線上の点であり, 圧力 $p_{\mathrm{d}}$ は $p_{\mathrm{a}}, p_{\mathrm{b}}$ より 外抻によって求める. 以上の方法により, 境界点における流 速および圧力を与え, 円管状の境界をもつ流路内の流れ解析 を行った。

\section{3. 計算結果および考察}

$3 \cdot 1$ 円管内のポアズイユ流れ はじめに, 本手法の 妥当性を評価するために, Fig. 4 に示すような $L_{x}=10 \Delta x$, 半径 $R$ の円管状の領域に扔けるポアズイユ流の解析を行った. 大口と出口は圧力差 $\Delta p$ をともなう周期境界条件とし, 管壁 はすべりなし壁条件とした. レイノルズ数は $\mathrm{Re}=u_{\max } R / \nu$ 


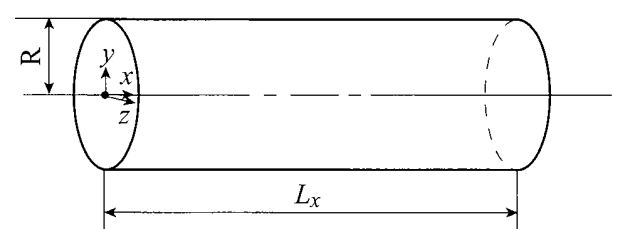

Fig. 4 Computational domain.

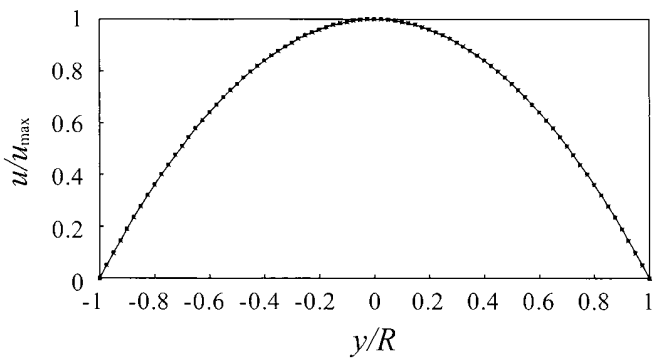

Fig. 5 Velocity profiles: interpolation; - , exact solution.

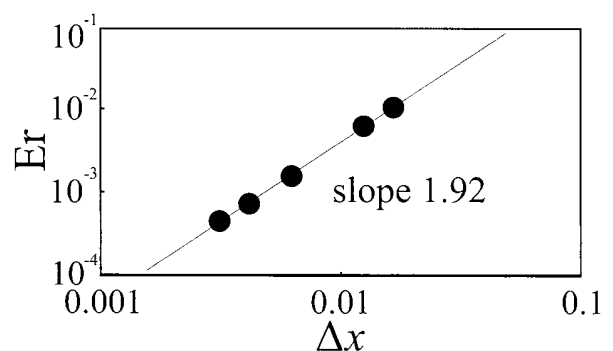

Fig. 6 Error norms.

と定義した.ここで, $u_{\max }$ は定常状態での最大流速であり， レは動粘性係数である。

計算結果の一例として $, R=40 \Delta x, R e=1.44$ に扔け る, $x=0.5 L_{x}, z=0.5 L_{z}$ の $y$ 方向の速度分布を Fig. 5 に示す．図には比較のために，同様の条件に打ける境界点 において流速および密度の線形補間を行った結果および厳 密解を示す，図より，㛜密解と本結果が良く一致しているこ とがわかる．また，このときの䛊差ノルムは，本手法では $\mathrm{Er}=0.008 \%$ ，線形補間では $\mathrm{Er}=0.07 \%$ となった. ここで, $\mathrm{E}_{\mathrm{r}}=\sum_{y} \sum_{z}\left|u^{*}-u\right| / \sum_{y} \sum_{z}\left|u^{*}\right|$ とした。 この結果より, 本手法は線形補間に比べて 10 倍程度精度が良いことがわかっ た.さらに, 格子点数を変化させ厳密解との䛊差ノルムを比較 した結果を Fig. 6 に示す．図より，本手法の収束速度が 1.92 であった。

$3 \cdot 2$ 円管内のポアズイユ流中における単一粒子の挙動 次に，提案した境界条件と二相系 LBM を用いて，Fig. 7 に 示すような円管内に球形粒子を一つ配置し，その後，圧力差 によって駆動される流れ場における粒子の挙動を計算した。 以下では，二相系 LBM における一相を界面張力を大きくす ることによって球形粒子 (固相) と見なすことにする。計算 条件は, $L_{x}=120 \Delta x, L_{y}=L_{z}=70 \Delta x$ の三次元領域に おいて, $y-z$ 平面の中心に直径 $D=80 \Delta x$, 主流方向の長 さが $L_{x}=120 \Delta x$ の円筒を配置し, 内部に直径 $d$ の粒子を 配置した．また，入口と出口は圧力差 $\Delta p$ をともなう周期境 界条件，管壁はすべりなし境界条件とし，圧力差を与え始め た時刻を $t=0$ とした，計算に抢けるパラメータは，固相お よび周囲の流体の粘性係数をそれぞれ $\nu_{\mathrm{p}}=5.0 \times 10^{-3} \Delta x$, $\nu_{c}=5.0 \times 10^{-3} \Delta x$ とし, 界面の厚さ, 界面張力に関する定 数をそれぞれ $\kappa_{f}=0.01(\Delta x)^{2} \kappa_{g}=0.02(\Delta x)^{2}$ で一定と した．また，レイノルズ数は $\mathrm{Re}=u_{\max } D / \nu_{\mathrm{c}}$ ，無次元時間 $t^{*}=t u_{\max } / d$ と定義した。 ここで, $u_{\max }$ は粒子が存在しな いときの定常状態における最大流速である.

計算結果の一例として $\operatorname{Re}=92$ において,$d=20 \Delta x$ の球 形粒子が初期位置 $\left(x / L_{x}, y / D, z / D\right)=(0.500,-0.167,0)$ よ り流動する様子を Fig. 8 に示す。 また, 粒子の中心位置の時

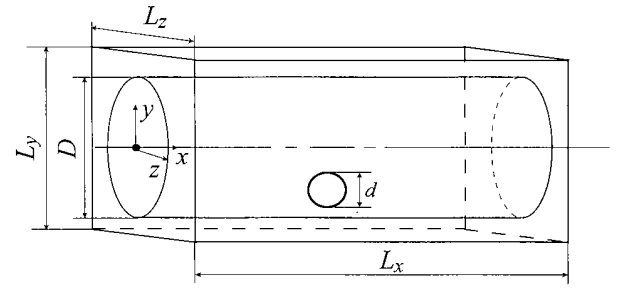

Fig. 7 Computational domain.
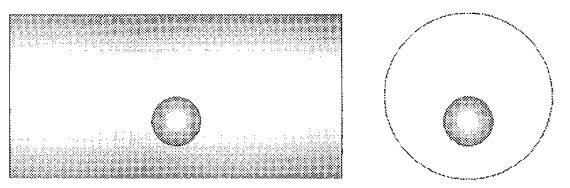

$t^{*}=0$

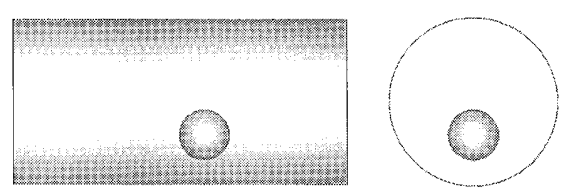

$t^{*}=4.21$

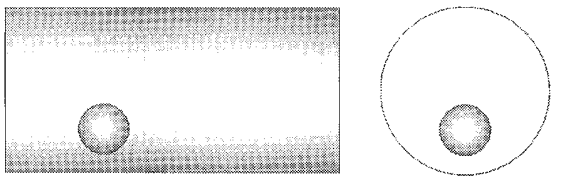

$t^{*}=18.0$

Fig. 8 Time evolution of particle position: side view (left); view from the outlet (right) $\left(t^{*}=\right.$ $\left.t u_{\max } / d\right)$.

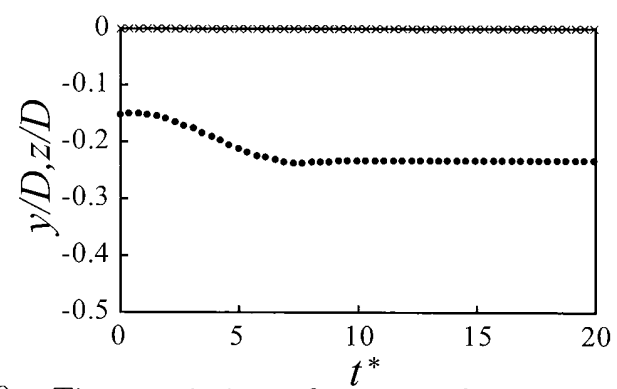

Fig. 9 Time variation of center of particle: $\bullet, y$ position; $\times, z$-position.

間変化を Fig. 9 に示す．両図より，粒子が管壁と中心軸の間 にある平衡位置に達する様子が確認できた. 本結果は, 流体 と等密度の剛体球が示す Segré-Silberberg 効果 ${ }^{(5)}$ と同様の現 象であると考えられる。

\section{4. お わりに}

既存の LBM においてアルゴリズムの簡単さを維持し，円 管形状をもつ流路に対する新たな境界条件を提案した。 円管 内のポアズイユ流れの計算を行い厳密解と比較した結果, 良 い一致が得られた.また, 二相系 LBM に本手法を組み込み, 円管内のポアズイユ流中における粒子の挙動のシミュレーショ ンを行った.

\section{文献}

（1）稲室隆二, 物性研究 77 (2001), pp. 197-232.

(2) Y. Peng, C. Shu, Y.T. Chew, X.D. Niu, X.Y. Lu, J. Comput. Phys. 218 (2006), pp. 460-478.

(3) C. Shu, N. Liu, Y.T. Chew, J. Comput. Phys. 226 (2007), pp. 1607-1622.

(4) T. Inamuro, R. Tomita, F. Ogino, Int. J. Mod. Phys. 17 (2003), pp. 21-26.

(5) G. Segré, A. Silberberg, Nature 189 (1961), pp. 181-193. 